\title{
Comparative analysis of bacterioplankton and phytoplankton in three ecological provinces of the northern South China Sea
}

\author{
Xiuren Ning ${ }^{1,2}$, William K. W. $\mathrm{Li}^{3, *}$, Yuming Cai ${ }^{1}$, Junxian Shi ${ }^{1}$ \\ ${ }^{1}$ The Second Institute of Oceanography, State Oceanic Administration (SOA), Hangzhou 310012, China \\ ${ }^{2}$ SOA Key Laboratories of Oceanic Dynamic Processes \& Satellite Oceanography and Submarine Sciences, Hangzhou 310012, China \\ ${ }^{3}$ Bedford Institute of Oceanography, Dartmouth, Nova Scotia B2Y 4A2, Canada
}

\begin{abstract}
The association between heterotrophic bacterioplankton and phytoplankton was examined in the northern region of the South China Sea where 3 marine biogeochemical provinces adjoin. The relationship between bacterial abundance and total chlorophyll a concentration was significant in the oceanic Archipelagic Deep Basin Province and in the China Sea Coastal Province, but not so in the Beibu Gulf (Sunda-Arafura Shelves Province). The importance of different phytoplankton groups (netplankton, nanoplankton and picoplankton, Synechococcus spp., Prochlorococcus spp. and picoeukaryotes) to bacteria was examined by multiple linear regression analysis. We found that bottomup control on bacteria depended strongly on the picoplankton size class of the phytoplankton, and particularly on the picocyanobacteria Synechococcus spp. Possible carbon transfer mechanisms suggest a plausible basis for the linkage of Synechococcus spp. to bacteria.
\end{abstract}

KEY WORDS: Phytoplankton · Photosynthetic picoplankton · Bacterioplankton · Northern South China Sea

\section{INTRODUCTION}

The South China Sea (SCS) is a vast marginal sea constituting one of the world's 50 so-called 'large marine ecosystems' (Sherman 2001). In geographic extent, the SCS covers 3.5 million $\mathrm{km}^{2}$, and comprises the waters bounded in the north by a horizontal line between Taiwan and mainland China at $25^{\circ} \mathrm{N}$, in the east by a vertical line between Taiwan and the Philippines at $121^{\circ} \mathrm{E}$ and a diagonal line above the Sulu Sea between the Philippines and Borneo, in the south by a horizontal line between Borneo and Sumatra at $3^{\circ} \mathrm{S}$, and in the west by a vertical line across the Malacca Strait at $103^{\circ} \mathrm{E}$ (Pauly \& Christensen 1993). The SCS comprises almost equal areas of the continental shelf $(54 \%)$ and the open ocean (46\%), partitioned by the $200 \mathrm{~m}$ isobath.

For the purpose of harvest fisheries management, the SCS can be divided into 10 subsystems: 2 in nearshore waters $(<10 \mathrm{~m}), 6$ on the shallow shelf (10 to $50 \mathrm{~m}$ ), 1 in the deep shelf (50 to $200 \mathrm{~m}$ ), and 1 in the open ocean beyond the shelf (Pauly \& Christensen 1993). However, for the purpose of investigating the response of plankton to regional oceanographical features, it is sufficient to differentiate merely 3 ecological provinces (Longhurst 1998, Ning et al. 2003)-the China Sea Coastal Province (CHIN), the Beibu Gulf (Sunda-Arafura Shelves Province, SUND), and the Archipelagic Deep Basin Province (ARCH). The first 2 overlie the continental shelf in a common coastal biome, the third the deep ocean in a trade wind biome.

It has been suggested that as a whole, the SCS sustains an average annual catch that is substantially below potential fish production (Pauly \& Christensen 1993, Sherman 2001). However, it is conceivable that an active microbial loop may divert primary production away from fisheries, leading to lower harvests than would presumably be otherwise possible. Unfor- 
tunately, the roles of heterotrophic bacterioplankton and photosynthetic picoplankton in the lower trophic levels of these waters have not been explicitly addressed. These microbial plankton are ubiquitous but have been little studied in the SCS until recently (Cai et al. 2002, Yang \& Jiao 2002, Agawin et al. 2003, Ning et al. 2003). In contrast, many studies in the neighbouring East China Sea (ECS), also belonging to the CHIN province, have confirmed the importance of photosynthetic picoplankton (Liu et al. 1997, Chen 2000), including species of cyanobacteria in the genera Synechococcus and Prochlorococcus (Vaulot \& Ning 1988, Ning et al. 1997, Chiang et al. 2002, Jiao et al. 2002, Chang et al. 2003a, Furuya et al. 2003). In the ECS, heterotrophic bacterial production is probably controlled interactively by substrate supply and temperature (Shiah et al. 2000, 2003).

In the portion of the SCS north of $17^{\circ} \mathrm{N}$, the 3 ecological provinces adjoin each other. West of Hainan Island, the continental shelf is part of SUND; to the east, the shelf is part of CHIN, whilst the deep open ocean is part of ARCH (Fig. 1). We have recently described the summer distribution pattern of picophytoplankton in this area (Ning et al. 2003). Herein, we examine the relationship between heterotrophic bacteria and phytoplankton to infer the relative degree to which these microbes are linked. Since bacteria are able or obliged to use the organic substrates originating from phytoplankton in various forms (e.g. excreted photosynthates, protistan egesta, cell lysates, etc.), these trophic groups are coupled to lesser or greater extents depending on the availability of substrates from other sources. A recent study suggested that a strong dependence of bacteria on algal extracellular production can only be expected in open ocean environments removed from allochthonous sources (Morán et al. 2002). Our study of the SCS investigated whether the bacteria-phytoplankton relationship is the same in all 3 provinces and found that it is not. We also determined which phytoplankton group had the greatest effect on this relationship and found this to comprise the picocyanobacteria Synechococcus spp.

\section{MATERIALS AND METHODS}

From 10 to 16 August 1999, we sampled 22 stations in the northern SCS, south of continental China (Fig. 1) from the RV 'Xiangyanghong' No. 14. West of Leizhou Peninsula and Hainan Island lies the Beibu Gulf (SUND), a semi-enclosed tropical bay running from $\mathrm{NE}$ to SW, and no greater than $60 \mathrm{~m}$ in depth. The

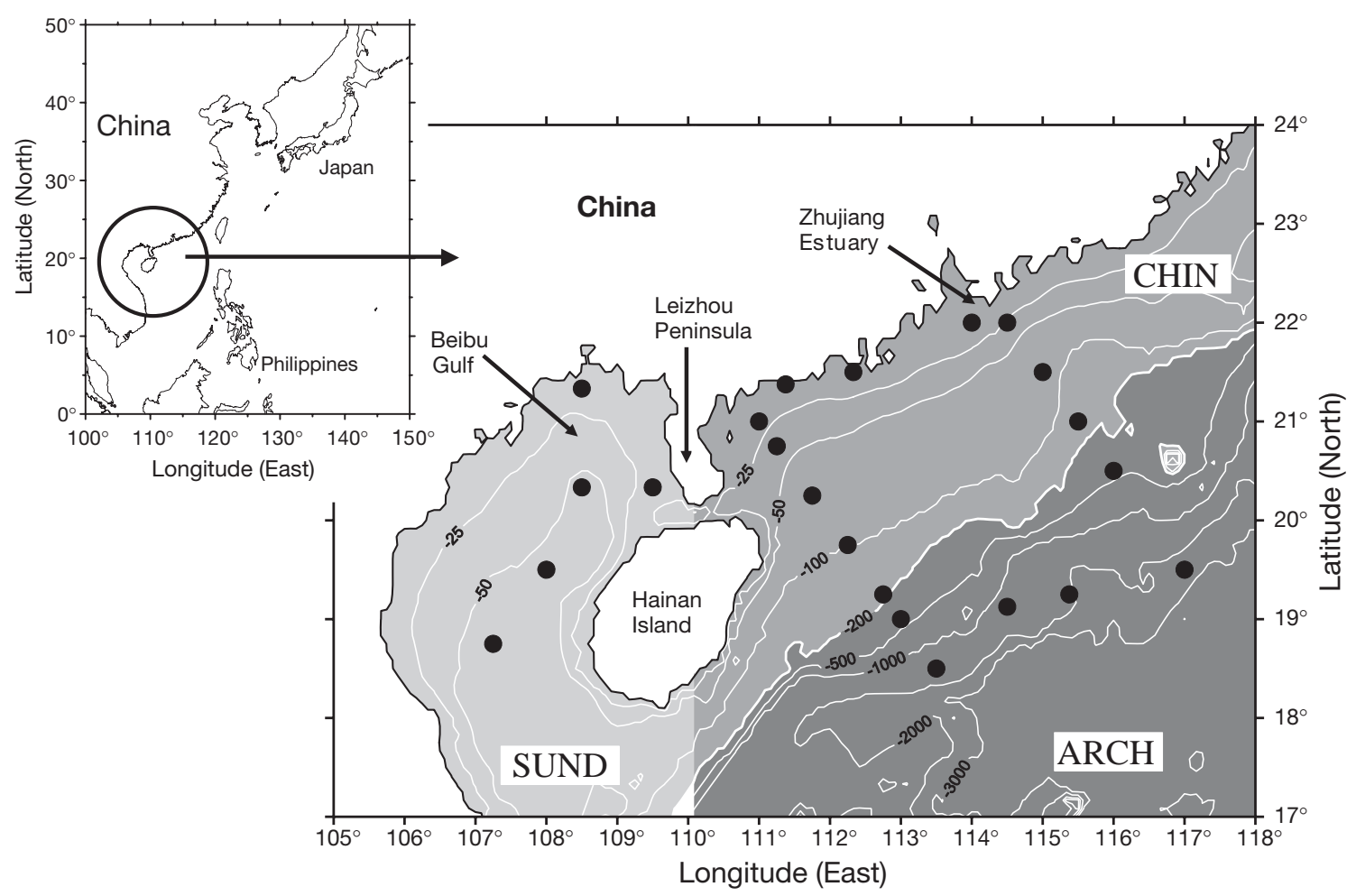

Fig. 1. South China Sea, showing 5 stations in the Sunda-Aratura Shelves Province (SUND), 10 stations in the China Sea Coastal Province (CHIN), and 7 stations in the Archipelagic Deep Basin Province (ARCH) sampled in present study 
Qiongzhou Strait connects these waters to the region east of Hainan Island, comprising the Zhujiang (Pearl River) Estuary, the Guangdong coastal zone and the extensive continental shelf (CHIN). The slope and open ocean lie SE beyond the $200 \mathrm{~m}$ isobath (ARCH). We occupied 5 stations in SUND, 10 in CHIN and 7 in ARCH.

At the deep-water stations, samples were collected in $5 \mathrm{dm}^{3}$ Niskin bottles from the surface and at depths of surface, 10, 30, 50, 75, 100 and $150 \mathrm{~m}$. At the shallow-water stations, fewer depths were sampled, but never less than 3 per station $(0,10$ and $20 \mathrm{~m})$. Aliquots of $1.8 \mathrm{~cm}^{3}$ were filled into cryogenic vials and fixed with $0.2 \mathrm{~cm}^{3}$ paraformaldehyde $(1 \%$ final concentration) for $10 \mathrm{~min}$ at room temperature, quickfrozen in liquid nitrogen, and stored at $-80^{\circ} \mathrm{C}$ until analysis (Marie et al. 1999). Picophytoplankton cells (the genera Prochlorococcus and Synechococcus, and picoeukaryotes) and heterotrophic bacteria were enumerated by flow cytometry using standard protocols (Marie et al. 1999) as previously described (Li et al. 1992, Li 1995, Li \& Dickie 2001). Briefly, picophytoplankton were detected by red autofluorescence of chlorophyll $a$, and the 3 groups identified by relative cell size (forward light scatter) and the presence of phycoerythrin (orange fluorescence). Bacteria were detected by green fluorescence after staining with the nucleic acid binding fluorochrome SYBR Green-1.

Chlorophyll a content was determined in the various size fractions of the plankton by filtering $150 \mathrm{~cm}^{3}$ seawater through $20 \mu \mathrm{m}$ mesh net (netplankton), a $2.0 \mu \mathrm{m}$ Nuclepore membrane filter (nanoplankton), and a Whatman GF/F glass fibre filter (picoplankton). The plankton thus retained was extracted in $90 \%$ acetone, and fluorescence was measured according to JGOFS protocol (Knap et al. 1996) using a Turner Designs model 10 fluorometer. Multiple linear regression analysis was performed according to Sokal \& Rohlf (1995) on log-transformed variables.

\section{RESULTS}

Following a first order pattern chlorophyll a concentration decreased with increasing bathymetric depth over the 3 ecological provinces (Fig. 2a). In shallow waters, there was generally more chlorophyll in the netplankton (Fig. 2b) and the nanoplankton (Fig. 2c)

Fig. 2. Relationship between chlorophyll (chl a) of phytoplankton and bathymetric depth. (a) Chl a concentration for entire phytoplankton assemblage; (b) \% chl $a$ in netplankton; (c) \% chl $a$ in nanoplankton; $(d) \% \mathrm{chl} a$ in picoplankton. $(\mathrm{O}, \mathrm{O})$ $\mathrm{ARCH}(\mathrm{n}=33) ;(\square, \square)$ CHIN $(\mathrm{n}=43) ;(\Delta, \Delta) \operatorname{SUND}(\mathrm{n}=23)$; grey symbols: samples collected at sea surface (nominal $0 \mathrm{~m}$ depth); open symbols: samples collected below sea surface
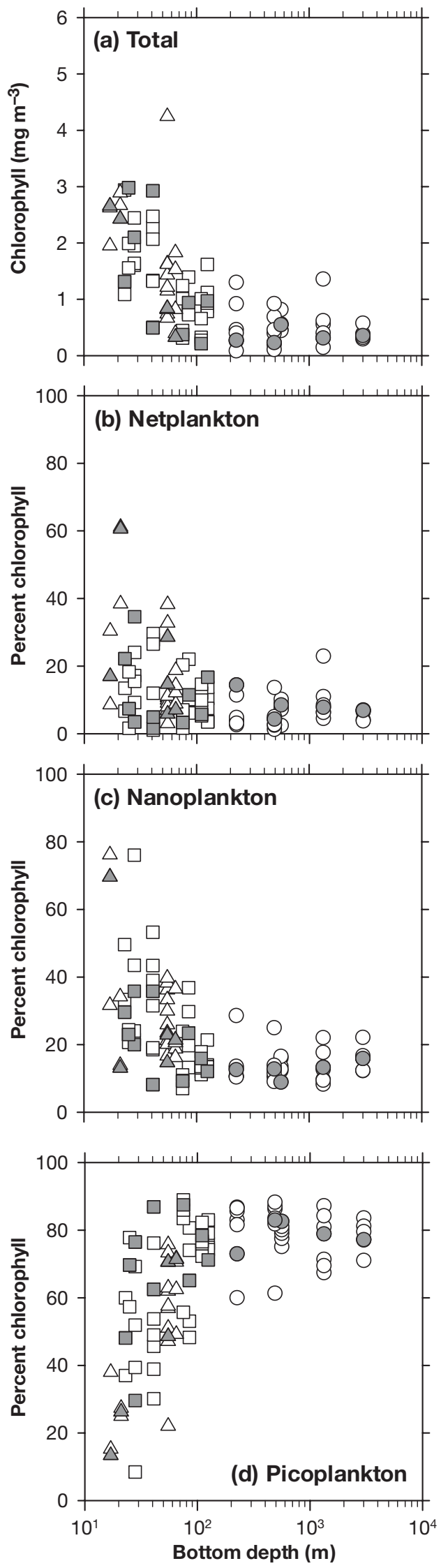
than in the picoplankton (Fig. 2d). Conversely, picoplankton accounted for the majority of chlorophyll a in deep waters (Fig. 2d). Also in a first order pattern, abundance of different picoplankton cells was related to increasing bathymetric depth; decreasing for Synechococcus. (Fig. 3a), picoeukaryotes (Fig. 3c) and heterotrophic bacteria (Fig. 3d), and increasing for Prochlorococcus. (Fig. 3b). Much of the variability in these first order trends was associated with factors related to the depth at which the plankton were collected-mainly irradiance, temperature and nutrient concentrations. The depth-related variability in these measurements can be circumvented by considering only those samples collected near the sea surface at (nominal) $0 \mathrm{~m}$ depth. After doing so, it becomes evident (Fig. 4) that the phytoplankton community changed from picoplankton dominance (ca. 85\%) in

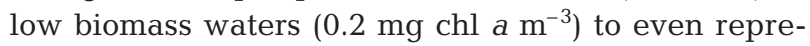
sentation by all 3 size classes (ca. $33 \%$ ) in high biomass waters $\left(13 \mathrm{mg} \mathrm{chl} \mathrm{m}{ }^{-3}\right)$.

These whole region trends of a concurrent decrease in phytoplankton and bacteria from nearshore to offshore indicate statistically significant positive relations between bacterial abundance and chlorophyll a content of each of the phytoplankton size fractions (Fig. 5), and between bacterial abundance and each of the 3 picophytoplankton groups (Fig. 6). The weakest relationship was that between bacteria and Prochlorococcus (Fig. 6b), indicative of their opposing cross-shelf trends (Fig. 3).

A different pattern for the bacteria-phytoplankton relationship was seen when each ecological province was examined separately. In $\mathrm{ARCH}$, the relationship was positive for chlorophyll a content of all phytoplankton size fractions (Fig. $7 \mathrm{a}, \mathrm{d}, \mathrm{g}, \mathrm{j}$ ) and for all picophytoplankton groups (Fig. 8a,d,g). However, in CHIN, bacterial abundance was not related to netplankton chlorophyll (Fig. 7e) and Prochlorococcus (Fig. 8e), and only weakly related to nanoplankton chlorophyll (Fig. 7h). The greatest difference between the trend for the whole region and that for a particular province was in SUND. Here, bacterial abundance did not increase with increasing chlorophyll a content of the various size fractions (Fig. $7 \mathrm{C}, \mathrm{f}, \mathrm{i}, \mathrm{l})$. Regional differences were reflected by Model II linear regression slopes of log bacteria on log total chlorophyll, which were 0.59 for the region as a whole, slightly higher (0.66) in $\mathrm{ARCH}$, slightly lower (0.51) in CHIN, and not statistically significant $(p>0.05)$ in SUND.

Fig. 3. Relationship between picoplankton cell abundance and bathymetric depth. (a) Synechococcus spp.; (b) Prochlorococcus spp.; (c) picoeukaryotic algae; (d) heterotrophic bacterioplankton. Further details as in Fig. 2, except that here for $\mathrm{ARCH} \mathrm{n}=49$
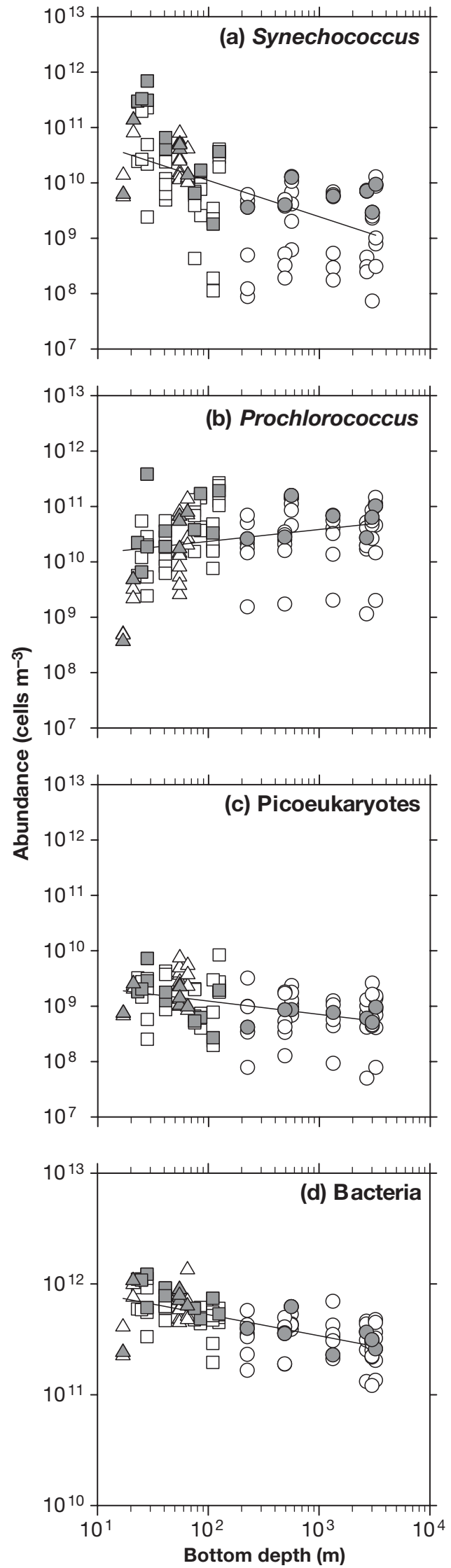

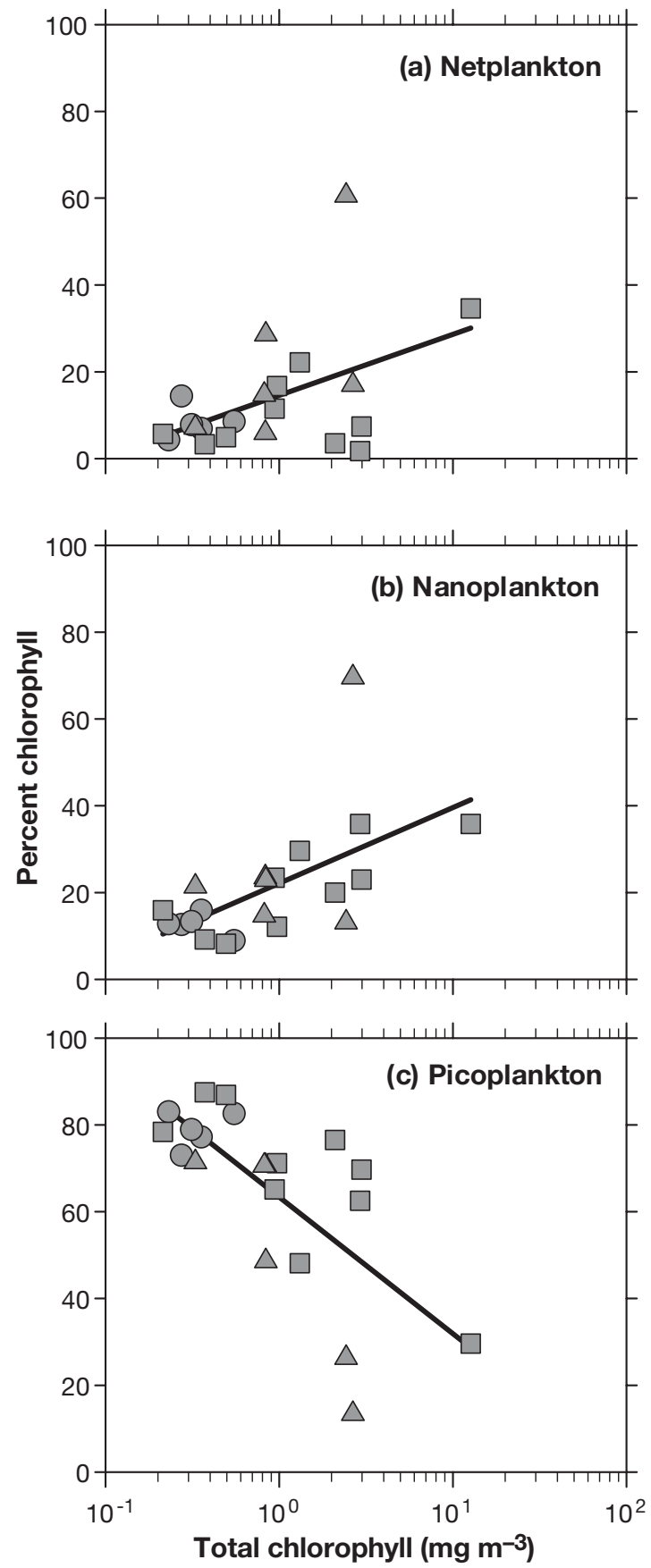

Fig. 4. Percentage contribution of (a) netplankton, (b) nanoplankton and (c) picoplankton to chlorophyll a biomass as a function of total chlorophyll a concentration in surface waters of the South China Sea (SCS). (O) $\mathrm{ARCH}_{i}(\square) \mathrm{CHIN}_{i}(\triangle)$ SUND

Fig. 5. Bivariate relationship between bacterial abundance and chlorophyll a content of different size fractions of phytoplankton in the entire SCS study region. (a) Total phytoplankton; (b) netplankton; (c) nanophytoplankton; (d) picophytoplankton. Proportion of explained variation is given by coefficient of determination $\left(\mathrm{r}^{2}\right) .{ }^{*}$ Statistically significant at $\mathrm{p}<0.01(\mathrm{n}=99)$. Symbols as in Fig. 4
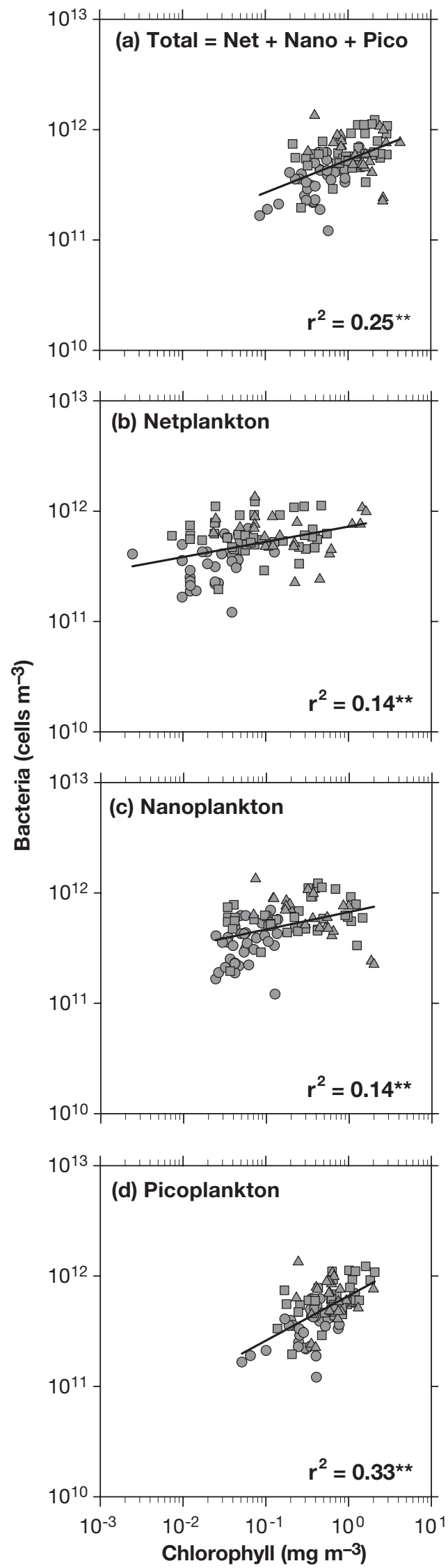

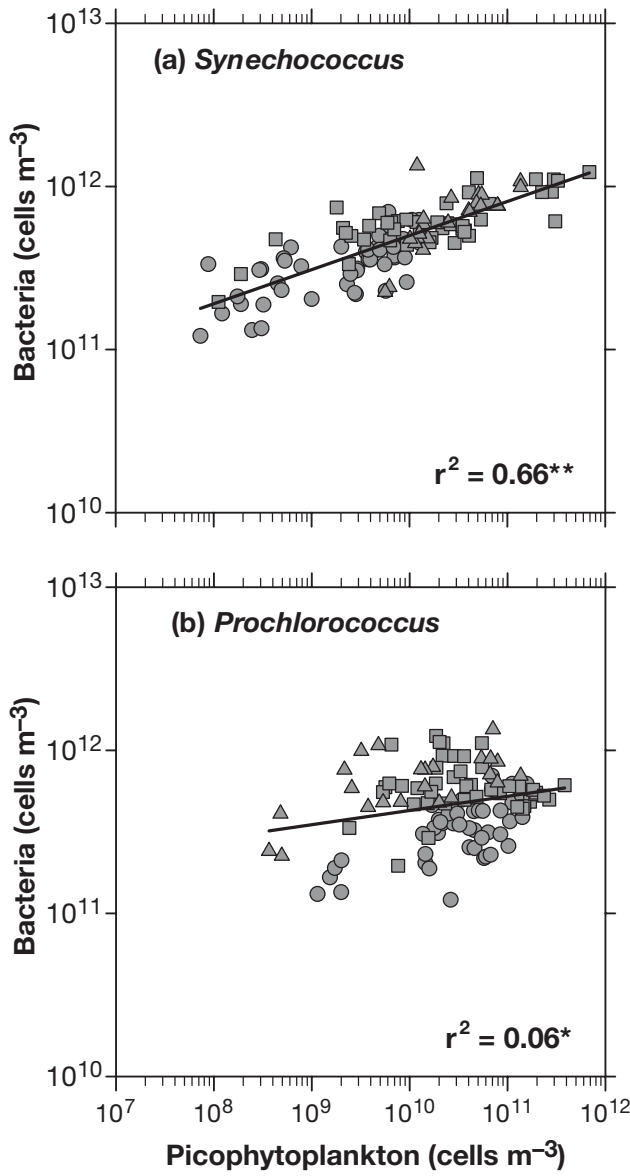

The bivariate correlations (Figs. 5 to 8) do not reveal the underlying separate dependence of bacterial abundance on the individual phytoplankton groups (chlorophyll size class or picophytoplankton cell type), because there is intercorrelation amongst the phytoplankton themselves. Multiple linear regression analysis (Sokal \& Rohlf 1995) is required to determine which of the phytoplankton groups affect bacteria significantly and appreciably, and to estimate the relative magnitude of the contributions of these groups. In short, we computed partial regression coefficients on

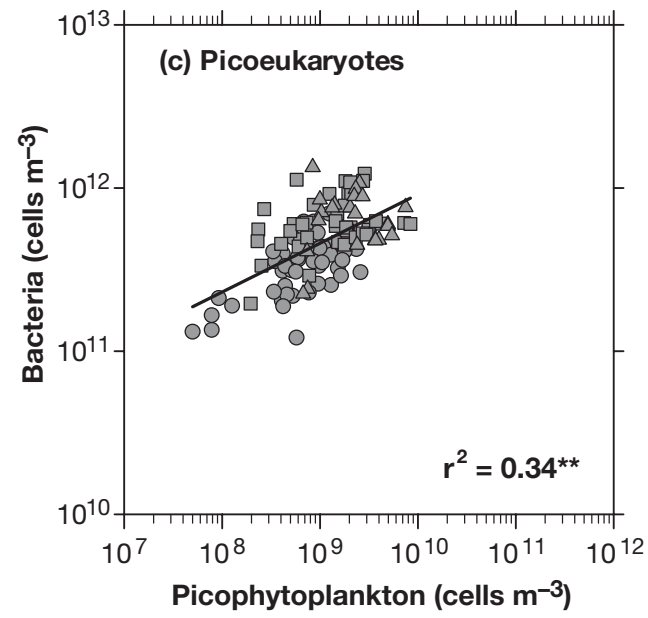

Fig. 6. Bivariate relationship between bacterial abundance and picophytoplankton cell abundance for the entire SCS study region. (a) Synechococcus spp.; (b) Prochlorococcus spp.; (c) picoeukaryotic algae. Proportion of explained variation is given by coefficient of determination $\left(\mathrm{r}^{2}\right) . * * *$ Statistically significant at $\mathrm{p}<0.05$ and $\mathrm{p}<0.01$, respectively $(\mathrm{n}=115)$. Symbols as in Fig. 4

the log-transformed variables, and present both the standard and conventional forms of these coefficients. The standard form ('beta coefficients') expresses the average change in standard deviation units of log bacteria for 1 SD change in log units of a particular phytoplankton group, all others being held constant. The conventional form expresses the average change in the variables in non-standardised measurement units. Because log-transformed variables are used, a rescaling of the untransformed measurements using fixed multiplicative factors (such as converting cell abundance to

Table 1. Multiple linear regression analysis of log bacterial abundance $(y)$ on log net-chlorophyll $\left(x_{1}\right)$, log nano-chlorophyll $\left(x_{2}\right)$, and log pico-chlorophyll $\left(\log x_{3}\right)$ in 3 biogeochemical provinces of the South China Sea. Standard partial regression coefficients are designated $b^{\prime}$,

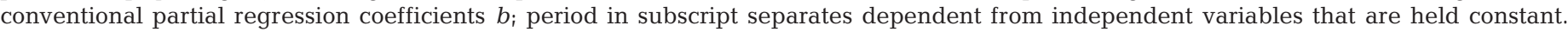
$\mathrm{R}^{2}$ : coefficient of multiple determination; $F_{\mathrm{s}}$ : sample statistic of the $F$-distribution; p: probability. $\mathrm{n}=33$ data points for ARCH, 43 for $C H I N$, 23 for SUND and 99 for the whole region (combined)

\begin{tabular}{|c|c|c|c|c|c|c|c|c|c|c|}
\hline Province & $\begin{array}{c}\text { Standard } p \\
x_{1}=\text { net chl } \\
b^{\prime}{ }_{y 1.2,3}\end{array}$ & $\begin{array}{c}\text { artial regressio } \\
x_{2}=\text { nano chl } \\
b_{Y 2.1,3}^{\prime}\end{array}$ & $\begin{array}{c}\text { coefficients } \\
x_{3}=\text { pico chl } \\
b_{y 3.1,2}^{\prime}\end{array}$ & $\begin{array}{r}\text { Conve } \\
y \text {-intercept } \\
a\end{array}$ & $\begin{array}{c}\text { entional parti } \\
x_{1}=\text { net chl } \\
b_{y 1.2,3}\end{array}$ & $\begin{array}{c}1 \text { regression co } \\
x_{2}=\text { nano chl } \\
b_{y 2.1,3}\end{array}$ & $\begin{array}{l}\text { efficients } \\
x_{3}=\text { pico chl } \\
\qquad b_{y 31,2}\end{array}$ & $\mathrm{R}_{y \cdot 1,2,3}^{2}$ & $F_{\mathrm{s}}$ & $\mathrm{p}$ \\
\hline $\mathrm{ARCH}+\mathrm{CHIN}+\mathrm{SUND}$ & 0.16 & -0.14 & 0.56 & 11.83 & 0.054 & -0.055 & 0.38 & 0.32 & 15.10 & $<0.0001$ \\
\hline $\mathrm{ARCH}$ & 0.17 & -0.63 & 0.98 & 11.31 & 0.092 & -0.52 & 0.60 & 0.40 & 6.35 & $<0.01$ \\
\hline CHIN & -0.43 & 0.24 & 0.56 & 11.75 & -0.12 & 0.072 & 0.29 & 0.33 & 6.29 & $<0.01$ \\
\hline SUND & 0.55 & -1.15 & 0.22 & 11.72 & 0.19 & -0.54 & 0.19 & 0.79 & 24.06 & $<0.0001$ \\
\hline
\end{tabular}



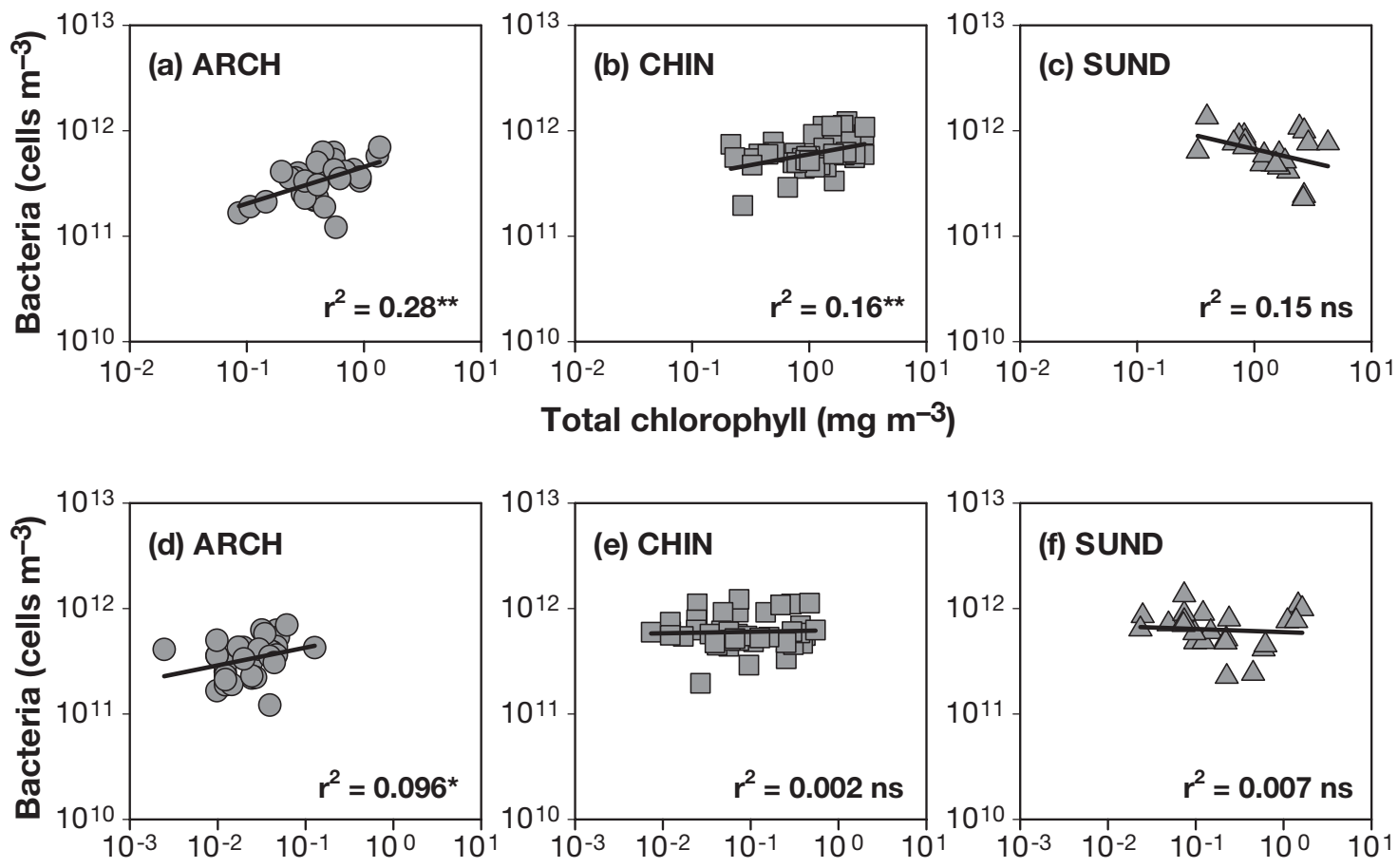

Net-chlorophyll $\left(\mathrm{mg} \mathrm{m}^{-3}\right)$
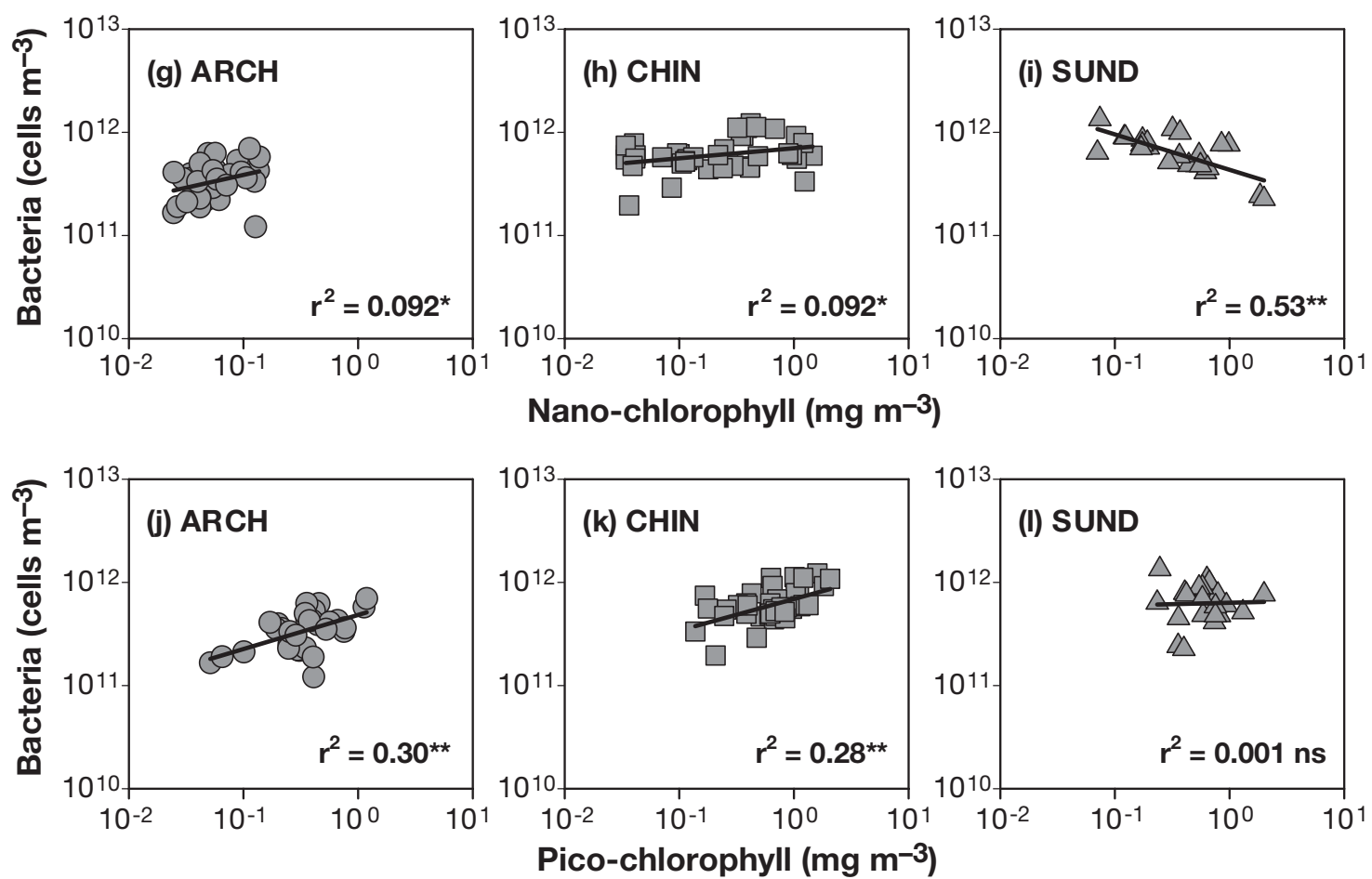

Fig. 7. Bivariate relationship between bacterial abundance and chlorophyll a content of different size fractions of phytoplankton in separate ecological provinces of $\operatorname{SCS}$ : $\operatorname{ARCH}(\bigcirc, n=33), \operatorname{CHIN}(\square, n=43)$, and $\operatorname{SUND}(\triangle, n=23)$. Further details as for Fig. 6

carbon biomass using carbon cell quota) affects only the $y$-intercept, and not the regression coefficients.

Multiple regression analysis revealed picophytoplankton to have the main effect on bacteria (Table 1).
In the study area as a whole, the beta coefficient for picoplankton chlorophyll (0.56) was the highest amongst the 3 size classes. On a regional basis, this coefficient was highest in ARCH (0.98), intermediate 

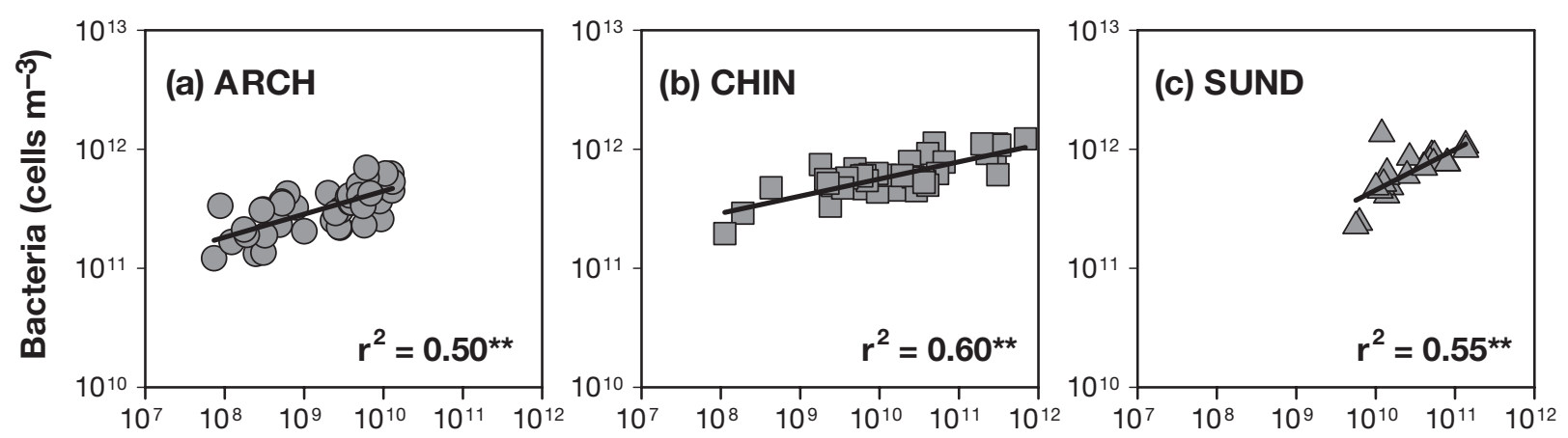

Synechococcus (cells $\mathrm{m}^{-3}$ )
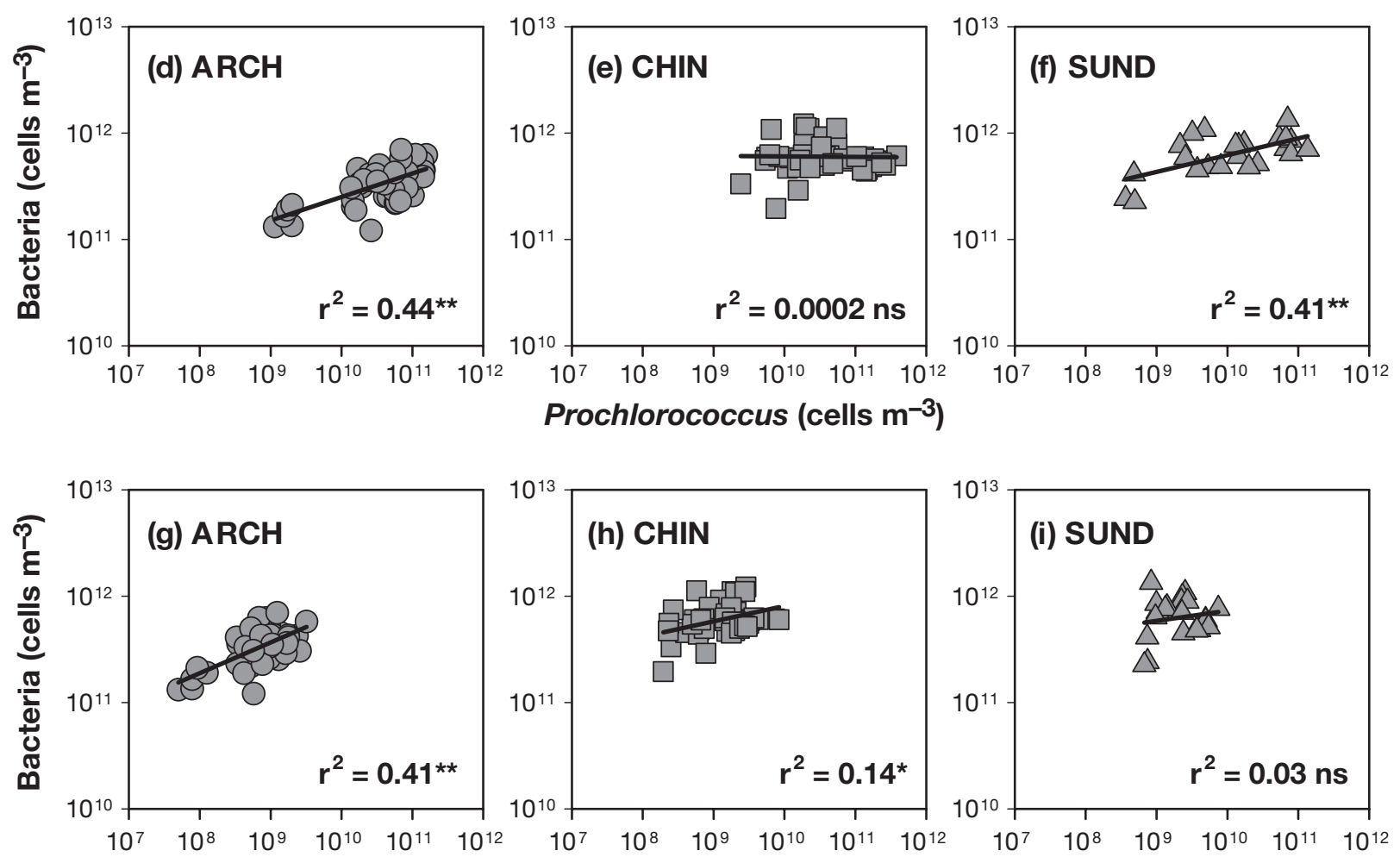

Picoeukaryotes (cells $\mathrm{m}^{-3}$ )

Fig. 8. Bivariate relationship between bacterial abundance and picophytoplankton cell abundance in separate ecological provinces of SCS: ARCH $(\bigcirc, \mathrm{n}=49), \mathrm{CHIN}(\square, \mathrm{n}=43=$, and $\operatorname{SUND}(\triangle, \mathrm{n}=23)$. Further details as for Fig. 6

Table 2. Multiple linear regression analysis of log bacterial abundance $(y)$ on log Synechococcus $\left(x_{4}\right)$, log Prochlorococcus $\left(x_{5}\right)$ and log picoeukaryotes $\left(\log x_{6}\right)$ in 3 biogeochemical provinces of the South China Sea. Symbols as in Table 1. $\mathrm{n}=49$ data points for ARCH, 43 for CHIN, 23 for SUND and 115 for the whole region (combined)

\begin{tabular}{|c|c|c|c|c|c|c|c|c|c|c|}
\hline \multirow[t]{2}{*}{ Province } & \multicolumn{3}{|c|}{ Standard partial regression coefficients } & \multicolumn{4}{|c|}{ Conventional partial regression coefficients } & \multirow[t]{2}{*}{$\mathrm{R}_{y, 4,5,6}^{2}$} & \multirow[t]{2}{*}{$F_{\mathrm{s}}$} & \multirow[t]{2}{*}{$\mathrm{p}$} \\
\hline & $\begin{array}{c}x_{4}=S y n \\
b^{\prime}{ }_{y 4.5,6}^{\prime}\end{array}$ & $\begin{array}{c}x_{5}=\operatorname{Pro} \\
b^{\prime}{ }_{y 5.4,6}^{\prime}\end{array}$ & $\begin{array}{c}x_{6}=\text { Euk } \\
b^{\prime}{ }_{y 6.4,5}\end{array}$ & $\begin{array}{c}y \text {-intercept } \\
a\end{array}$ & $\begin{array}{c}x_{4}=S y n \\
b_{y 4.5,6}\end{array}$ & $\begin{array}{c}x_{5}=\operatorname{Pro} \\
b_{y 5.4,6}\end{array}$ & $\begin{array}{c}x_{6}=\text { Euk } \\
b_{y 6.4,5}\end{array}$ & & & \\
\hline $\mathrm{ARCH}+\mathrm{CHIN}+\mathrm{SUND}$ & 0.71 & 0.061 & 0.14 & 8.97 & 0.18 & 0.022 & 0.074 & 0.67 & 76.84 & $<0.0001$ \\
\hline $\mathrm{ARCH}$ & 0.63 & -0.21 & 0.52 & 8.57 & 0.17 & -0.071 & 0.24 & 0.64 & 26.30 & $<0.0001$ \\
\hline CHIN & 0.84 & -0.18 & -0.055 & 10.95 & 0.16 & -0.054 & -0.021 & 0.63 & 22.21 & $<0.0001$ \\
\hline SUND & 0.63 & 0.48 & -0.063 & 7.96 & 0.29 & 0.12 & -0.038 & 0.76 & 20.27 & $<0.0001$ \\
\hline
\end{tabular}


in CHIN (0.56), and lowest in SUND (0.22). In contrast, the coefficient for netplankton chlorophyll was appreciable in SUND (0.55), but low in ARCH (0.17).

Within the picophytoplankton size class, Synechococcus had the main effect (Table 2). The beta coefficient for Synechococcus was high on a region-wide basis (0.71) and did not differ greatly amongst the provinces $(0.62$ to 0.84$)$. In contrast, the beta coefficient for Prochlorococcus was very low on a region-wide basis (0.06), and even negative in $\mathrm{ARCH}$ and $\mathrm{CHIN}$. The beta coefficient for picoeukaryotes was appreciably high only in ARCH (0.52).

\section{DISCUSSION}

Comparative analysis in ecology (Cole et al. 1991) is the statistical evaluation of observations across nature's gradients aimed at identifying broad patterns and at inferring possible underlying rules. In aquatic microbial ecology, the comparative approach has provided much insight into food web structure, dynamics and function (Gasol \& Duarte 2000). In particular, the regulation of bacteria by carbon resources has been extensively studied (Pace \& Cole 1994). The basis of this regulation is the trophic dependence of bacteria on phytoplankton; i.e. heterotrophic bacteria require labile organic molecules for growth, and these are made available by phytoplankton.

In systems where bacteria are carbon limited, the extent to which dissolved primary production satisfies bacterial carbon demand is a direct and quantitative measure of trophic coupling (Morán et al. 2002). A less direct indication of coupling is the extent to which bacterial abundance changes in relation to bacterial production, the latter being a surrogate for the steady state flux of dissolved organic substrates (Billen et al. 1990, Ducklow 1992). An even less direct indication of coupling is the extent to which bacterial abundance changes in relation to chlorophyll concentration. Clearly, bacterial abundance is not a robust proxy for bacterial carbon demand, and neither is chlorophyll concentration a robust proxy for dissolved primary productivity. Nevertheless, the ease with which bacterial abundance and chlorophyll concentration can be measured has allowed an extensive examination of their statistical relationship to each other. This relationship, described by linear regression of the logtransformed variables, is always positive but less than proportional (Gasol \& Duarte 2000). In a survey of 33 studies in different freshwater and marine ecosystems, the power slope ranged from 0.2 to 0.8 , and averaged $0.47 \pm 0.03$, leading Gasol \& Duarte (2000) to state that this is one of the few undisputed patterns in aquatic microbial ecology. A power slope of less than 1 indi- cates that bacterial abundance is highest (in relation to phytoplankton biomass) in low chlorophyll waters. However, it is unclear whether this means that bacteria are more abundant than is supportable by the resources available in oligotrophic waters, or conversely that bacteria are too sparse for the resources available in mesotrophic waters (Gasol \& Duarte 2000).

At the largest scale of our observation, which was a region covering the juncture of the 3 provinces of $\mathrm{ARCH}, \mathrm{CHIN}$ and SUND, the first-order patterns in the distribution of chlorophyll $a$ and microbial plankton were as expected from general considerations (Agawin et al. 2000, Cai et al. 2002), from studies in neighbouring areas (Chen 2000, Chiang et al. 2002, Jiao et al. 2002), and from climatological averages (Xie et al. 2003). Picophytoplankton comprised the greater portion part of phytoplankton biomass in warm, nutrient-poor offshore waters (Figs. 2d \& 4c), but these waters sustained low absolute abundances of Synechococcus, picoeukaryotes and bacteria (Fig. 3). Also at this large scale, the expected coupling between bacteria and total chlorophyll was confirmed (Fig. 5a). The slope of the Model II bivariate regression (0.59) was slightly higher than the grand global mean of 0.46 (Li et al. 2004), but compared well with that in other ecosystems (Gasol \& Duarte 2000). Since the carbon:chlorophyll a ratio of phytoplankton has been shown to increase from coastal to offshore waters in the ECS due to changes in species composition as well as in light and nutrient conditions (Chang et al. 2003b), it is possible that the actual coupling of bacterial carbon demand to dissolved primary production is weaker than indicated by the relationship of bacterial abundance to chlorophyll a.

At the finer level of individual provinces, the patterns were idiosyncratic. Most notably, the positive correlation between bacteria and total chlorophyll weakened from ARCH to CHIN to SUND (Fig. 7a,b,c). Less positive (including zero) slopes between bacteria and their resource supply are generally interpreted as evidence for stronger top-down control or allochthonous carbon subsidies (Ducklow 1992, Pace \& Cole 1994, Gasol \& Duarte 2000). Recent studies in the southern ECS suggest the importance of dissolved organic carbon from non-phytoplankton and allochthonous sources in supporting bacterial carbon demand (Shiah et al. 2000, 2003) and high rates of microbial plankton respiration (Chen et al. 2003). Further north, in the Yellow Sea, bacteria are also uncoupled from phytoplankton, apparently because strong tides mix the organic matter produced in the euphotic zone into the deeper water column (Cho et al. 1994). In both the SCS and ECS, it therefore appears that bacteria are coupled to phytoplankton most strongly in the offshore biome in a pattern stereotypic for open ocean waters 
(Ducklow 1992). In the coastal biome, the hydrodynamic features are complex (Xue et al. 2001) and include estuarine plumes that carry heavy anthropogenic loads (Yin et al. 2001) and also the likelihood of enhanced bacterivore populations (Chiang et al. 2003). Furthermore, the shallow waters of the Beibu Gulf (SUND) contain substantial areas of coral reefs, mangroves and seagrasses. These additional potential sources of substrate supply or grazing pressure would reduce the apparent linkage of bacteria to phytoplankton.

Where the bacteria-chlorophyll relationship was significant, this was mainly attributable to the picoplankton. The proportion of bacterial variation explained solely by picoplankton chlorophyll in ARCH $\left(r^{2}=0.30\right)$ and in CHIN $\left(r^{2}=0.28\right)$ was only slightly less than that explained by joint consideration of all 3 chlorophyll size fractions $\left(\mathrm{R}^{2}=0.40\right.$ and 0.33 respectively, Table 1). Since this relationship depended greatly on Synechococcus, and to some extent on picoeukaryotes, but not on Prochlorococcus (as indicated by the partial regression coefficients, shown in Table 2), the question arises as to whether these picoplankters differ in the efficiency with which they transfer carbon to bacteria via the dissolved carbon pool. An alternative explanation for the observed correlation between bacteria and phytoplankton is that they were responding independently to the same set of forcing factors. For example, conditions supporting high dissolved organic matter (DOM) supply to heterotrophs might also support selective alleviation of trace metal inhibition of phototrophs (Sherr et al. 2004). Be that as it may, the evidence for a causal link between picophytoplankton and bacteria is strong. The transfer processes include exudation of organic photosynthates by healthy picoplankters, the release of DOM in the egesta of protozoans that have consumed the picoplankters, and the liberation of cellular contents by viral lysis or autolysis (Nagata 2000).

Several lines of evidence point to a low transfer of carbon from Prochlorococcus to the dissolved pool. First, we surmise that the direct efflux of soluble carbon from Prochlorococcus is low. We are unaware of direct evidence on the rate of extracellular release by picophytoplankters, but group-specific primary production often decreases in the order picoeukaryotes, Synechococcus, Prochlorococcus (Li 1994, 1995), reflecting the same order in specific growth rate and cellular carbon content (Worden et al. 2004). Generally, phytoplankton release about 10 to $20 \%$ of primary production as exudates, but this is thought to be insufficient to meet bacterial carbon demand (Nagata 2000).

Second, there may be differences in the efficiency with which phagotrophic flagellates assimilate different picophytoplankters, implying that the non- assimilated fraction is different. Guillou et al. (2001) found that although the stramenopile Picophagus flagellatus ingested both Synechococcus and Prochlorococcus, the former was poorly digested and supported less growth. The efficiency of carbon transfer was less than $1 \%$ for Synechococcus compared to $23 \%$ for Prochlorococcus. In other words, as a result of protozoan grazing on picophytoplankters, less of the carbon from Prochlorococcus (and more from Synechococcus) was potentially available for heterotrophic bacteria. The trophic flow model of Nagata (2000) suggested that grazers, particularly protozoans, are the major contributors to DOM production. If it is generally true that a substantial portion of Synechococcus spp. carbon is released to the dissolved organic pool and made available to bacteria, then this would be a plausible basis for their strong coupling observed in the SCS.

Third, although it is known that phytoplankters are susceptible to viral infection (Fuhrman 1999, Sullivan et al. 2003) and automortality (Berges \& Falkowski 1998, Veldhuis et al. 2001), there is insufficient information to evaluate the relative extent to which Synechococcus, Prochlorococcus and picoeukaryotes would each contribute to the DOM pool upon lysis. On the basis of cell membrane integrity, it appears that populations of Synechococcus generally contain proportionately more viable cells than those of picoeukaryotes (Veldhuis et al. 2001, Agustí \& Sánchez 2002) and Prochlorococcus (Agustí 2004). However, an assay of membrane permeability presumably does not distinguish between lysis induced by autogenic factors or by viruses. Other evidence suggests that viruses are likely to have a significant role in shaping phytoplankton species composition (Fuhrman 1999). Recent genomic analyses of marine picocyanobacteria indicate differences in genes that control cell surface chemistry, providing a basis for selective phage recognition, and possibly also selective recognition by protist grazers (Rocap et al. 2003). New information on viruses regarding their host strain specificity and titres (Sullivan et al. 2003) are consistent with a view that Synechococcus spp. are commonly susceptible to viralinduced mortality, and that this decreases along a trophic gradient from coastal to open ocean waters. The contribution of phytoplankton lysis to carbon flow in the microbial web can be modelled (Fuhrman 1999), but there is yet insufficient information for separate parameterisation of Synechococcus, Prochlorococcus and picoeukaryotes.

In the SCS as a whole, and in the provinces of $\mathrm{ARCH}$, CHIN and SUND taken separately, Synechococcus spp. were the only picophytoplankters with a consistent strong relationship to heterotrophic bacteria (Table 2). The coupling mechanisms of photosynthate 
exudation, protozoan egestion and cell lysis together provide a plausible basis for this particular linkage, but we cannot exclude the possibility that the correlations have no cause-and-effect basis. These inferences, arising from our comparative analysis, point to research questions that could be tested in future by direct experimentation.

Acknowledgements. We thank the National Nature Science Foundation of China (NSFC, No. 40176035 and 90211021) and the Department of Fisheries and Oceans (Canada) for financial support. The Department of Science and Technology, SOA, and the South China Sea Branch, SOA provided support and arrangements for the oceanographic research vessel. The captain and crew of the vessel 'Xiangyanghong' No. 14 helped in marine operations, and the South China Sea Branch, SOA, provided hydrological and chemical data.

\section{LITERATURE CITED}

Agawin NSR, Duarte CM, Agustí S (2000) Nutrient and temperature control of the contribution of picoplankton to phytoplankton biomass and production. Limnol Oceanogr 45:591-600

Agawin NSR, Duarte CM, Agustí S, McManus L (2003) Abundance, biomass and growth rates of Synechococcus sp. in a tropical coastal ecosystem (Philippines, South China Sea). Estuar Coast Mar Sci 56:493-502

Agustí S (2004) Viability and niche segregation of Prochlorococcus and Synechococcus cells across the Central Atlantic Ocean. Aquat Microb Ecol 36:53-59

Agustí S, Sánchez MC (2002) Cell viability in natural phytoplankton communities quantified by a membrane permeability probe. Limnol Oceanogr 47:818-828

Berges JA, Falkowski PG (1998) Physiological stress and cell death in marine phytoplankton: induction of proteases in response to nitrogen or light limitation. Limnol Oceanogr 43:129-135

Billen G, Servais P, Becquevort S (1990) Dynamics of bacterioplankton in oligotrophic and eutrophic aquatic environments: bottom-up or top-own control? Hydrobiologia 207:37-42

Cai Y, Ning X, Liu C (2002). Distribution of size-fractionated chlorophyll $a$ and primary production in the southern South China Sea and Beibu Gulf. Stud Mar Sin 44:11-21

Chang J, Lin KH, Chen KM, Gong GC, Chiang KP (2003a) Synechococcus growth and mortality rates in the East China Sea: range of variations and correlation with environmental factors. Deep-Sea Res Part II 50:1265-1278

Chang J, Shiah FK, Gong GC, Chiang KP (2003b) Crossshelf variation in carbon-to-chlorophyll a ratios in the East China Sea, summer 1998. Deep-Sea Res Part II 50: 1237-1247

Chen CC, Shiah FK, Gong GC, Chiang KP (2003) Planktonic community respiration in the East China Sea: importance of microbial consumption of organic carbon. Deep-Sea Res Part II 50:1311-325

Chen YLL (2000) Comparisons of primary productivity and phytoplankton size structure in the marginal regions of southern East China Sea. Cont Shelf Res 20:437-458

Chiang KP, Kuo MC, Chang J, Wang RH, Gong GC (2002) Spatial and temporal variation of the Synechococcus population in the East China Sea and its contribution to phytoplankton biomass. Cont Shelf Res 22:3-13
Chiang KP, Lin CY, Lee CH, Shiah FK, Chang J (2003) The coupling of oligotich ciliate populations and hydrography in the East China Sea: spatial and temporal variations. Deep-Sea Res Part II 50:1279-1293

Cho BY, Choi JK, Chung CS, Hong GH (1994) Uncoupling of bacteria and phytoplankton during a spring diatom bloom in the mouth of the Yellow Sea. Mar Ecol Prog Ser 113: 181-190

Cole J, Lovett G, Findlay S (1991) Comparative analyses of ecosystems: processes, mechanisms and theories. Springer-Verlag, New York

Ducklow HW (1992) Factors regulating bottom-up control of bacteria biomass in open ocean plankton communities. Ergebn Limnol 37:207-217

Fuhrman J (1999) Marine viruses and their biogeochemical and ecological effects. Nature 399:541-548

Furuya K, Hayashi M, Yabushita Y, Ishikawa A (2003) Phytoplankton dynamics in the East China Sea in spring and summer as revealed by HPLC-derived pigment signatures. Deep-Sea Res Part II 50:367-387

Gasol JM, Duarte CM (2000) Comparative analyses in aquatic microbial ecology: How far do they go? FEMS Microbiol Ecol 31:99-106

Guillou L, Jacquet S, Chrétiennot-Dinet MJ, Vaulot D (2001) Grazing impact of 2 picoplanktonic heterotrophic flagellates on Prochlorococcus and Synechococcus. Aquat Microb Ecol 26:201-207

Jiao N, Yang Y, Koshikawa H, Watanabe M (2002) Influence of hydrographic conditions on picoplankton distribution in the East China Sea. Aquat Microb Ecol 30:37-48

Knap A, Michaels A, Close A, Ducklow H, Dickson A (eds) (1996) Protocols for the Joint Global Ocean Flux Study (JGOFS) Core measurements. JGOFS Report No. 19. Reprint of the IOC Manuals and Guides No. 29, 1994. UNESCO, Paris

Li WKW (1994) Primary production of prochlorophytes, cyanobacteria, and eucaryotic ultraphytoplankton: measurements from flow cytometric sorting. Limnol Oceanogr 39: $169-175$

Li WKW (1995) Composition of ultraphytoplankton in the central North Atlantic. Mar Ecol Prog Ser 122:1-8

Li WKW, Dickie PM (2001) Monitoring phytoplankton, bacterioplankton, and virioplankton in a coastal inlet (Bedford Basin) by flow cytometry. Cytometry 44:236-246

Li WKW, Dickie PM, Irwin BD, Wood AM (1992) Biomass of bacteria, cyanobacteria, prochlorophytes and photosynthetic eukaryotes in the Sargasso Sea. Deep-Sea Res 39: $501-519$

Li WKW, Head EJH, Harrison WG (2004) Macroecological limits of heterotrophic bacterial abundance in the ocean. Deep-Sea Res Part I 51:1529-1540

Liu Z, Ning X, Shi J, Cai Y (1997) The standing stock and production of phytoplankton in Penaeus orientalis restocking water of the Xiangshan Bay. Acta Oceanol Sin 19:109-115

Longhurst A (1998) Ecological geography of the sea. Academic Press, San Diego, CA

Marie D, Partensky F, Vaulot D, Brussaard C (1999) Enumeration of phytoplankton, bacteria, and viruses in marine samples. In: Robinson JP, Darzynkiewicz Z, Dean PN, Orfao A, Rabinovitch PS, Stewart CC, Tanke HJ, Wheeless LL (eds) Current protocols in cytometry, Suppl 10, Unit 11. John Wiley \& Sons, New York, p 1-15

Morán XAG, Estrada M, Gasol JM, Pedrós-Alió C (2002) Dissolved primary production and the strength of phytoplankton-bacterioplankton coupling in contrasting marine regions. Microb Ecol 44:217-223

Nagata T (2000) Production mechanisms of dissolved organic 
matter. In: Kirchman DL (ed) Microbial ecology of the oceans. Wiley-Liss, New York, p 121-152

Ning X, Shi J, Liu Z, Cai Y (1997) Abundance and distribution of photosynthetic picoplankton in the Xiangshan Bay and the environmental controls. Acta Oceanol Sin 19:87-95

Ning X, Cai Y, Li G, Shi J (2003) Photosynthetic picoplankton in the northern South China Sea. Acta Oceanol Sin 25: 83-97

Pace ML, Cole JJ (1994) Comparative and experimental approaches to top-down and bottom-up regulation of bacteria. Microb Ecol 28:181-193

Pauly D, Christensen V (1993) Stratified models of large marine ecosystems: a general approach and an application to the South China Sea. In: Sherman K, Alexander LM, Gold BD (eds) Large marine ecosystems: stress mitigation, and sustainability. American Association for the Advancement of Science, Washington, DC, p 148-174

Rocap G, Larimer FW, Lamerdin J, Malfatti S and 20 others (2003) Genome divergence in two Prochlorococcus ecotypes reflects oceanic niche differentiation. Nature 424: $1042-1047$

Sherman K (2001) Large marine ecosystems. In: Steele JH, Thorpe SA, Turekian KK (eds) Encyclopedia of ocean sciences. Academic Press, London, p 1462-1469

Sherr EB, Sherr BF, Wheeler PA (2005) Distribution of coccoid cyanobacteria and small eukaryotic phytoplankton in the upwelling ecosystem off the Oregon coast during 2001 and 2002. Deep-Sea Res Part II 52:317-330

Shiah FK, Liu KK, Kao SJ, Gong GC (2000) The coupling of bacterial production and hydrography in the southern East China Sea: spatial patterns in spring and fall. Cont Shelf Res 20:459-477

Shiah FK, Gong GC, Chen CC (2003) Seasonal and spatial variation of bacterial production in the continental shelf of the East China Sea: possible controlling mechanisms and

Editorial responsibility: Evelyn \& Barry Sherr (Contributing Editors), Corvallis, Oregon, USA potential roles in carbon cycling. Deep-Sea Res Part II 50:1295-1309

Sokal RR, Rohlf FJ (1995) Biometry. The principles and practice of statistics in biological research, 3rd edn. WH Freeman, New York

Sullivan MB, Waterbury JB, Chisholm SW (2003) Cyanophages infecting the oceanic cyanobacterium Prochlorococcus. Nature 424:1047-1051

Vaulot D, Ning X (1988) Abundance and cellular characteristics of marine Synechococcus spp. in the dilution zone of the Changjiang (Yangtze River, China). Cont Shelf Res 8:1171-1186

Veldhuis MJW, Kraay GW, Timmermans KR (2001) Cell death in phytoplankton: correlation between changes in membrane permeability, photosynthetic activity, pigmentation and growth. Eur J Phycol 36:167-177

Worden AZ, Nolan JK, Palenik B (2004) Assessing the dynamics and ecology of marine picophytoplankton: the importance of the eukaryotic component. Limnol Oceanogr 49: $168-179$

Xie SP, Xie Q, Wang D, Liu WT (2003) Summer upwelling in the South China Sea and its role in regional climate variations. J Geophys Res C 108:3261-3273

Xue H, Chai F, Xu D, Shi, M (2001) Characteristics and seasonal variation of the coastal currents in the South China Sea. In: Xue H, Chai F, Xu J (eds) Oceanogaphy in China. China Ocean Press, Beijing, p 64-75

Yang Y, Jiao N (2002) In situ daily growth rate of Prochlorococcus at the chlorophyll maximum layer in the southern South China Sea: an estimation from cell cycle analysis. Chin J Oceanol Limnol 20(Spec Iss):8-14

Yin K, Qian PY, Wu MCS, Chen JC, Huang L, Song X, Jian W (2001) Shift from P to N limitation of phytoplankton growth across the Pearl River estuarine plume during summer. Mar Ecol Prog Ser 221:17-28

Submitted: June 24, 2004; Accepted: November 9, 2004

Proofs received from author(s): May 2, 2005 